\title{
Daya Tangkap Siswa Terhadap Pesan Moral Dan Nilai Karakter Pada Film Animasi Moana
}

\author{
Faridatul Fatriyah1 ${ }^{*}$, Singgih Adhi Prasetyo ${ }^{2}$, Asep Ardiyanto ${ }^{3}$ \\ ${ }^{1,2,3}$ Prodi Program Studi Pendidikan Guru Sekolah Dasar, Universitas PGRI Semarang, Semarang, Indonesia \\ *Corresponding author: fatriafarida@gmail.com
}

\begin{abstract}
Penelitian ini dilatar belakangi oleh hasil observasi yang menunjukkan bahwa siswa sekolah dasar memiliki intensitas waktu yang sering dalam menonton tayangan televisi ketika berada di rumah. Padahal terdapat beberapa tayangan di televisi yang tidak diperuntukkan untuk siswa sekolah dasar. Hal tersebut yang menjadikan dasar peneliti untuk menganalisis nilai-nilai karakter yang ada pada film animasi Moana. Tujuan penelitian ini adalah untuk mengetahui daya tangkap siswa sekolah dasar dalam menangkap pesan moral dan nilai-nilai karakter pada film animasi Moana. Jenis penelitian ini adalah penelitian kualitatif dengan metode deskriptif. Teknik pengumpulan data menggunakan metode simak catat, wawancara, observasi, dan dokumentasi. Penelitian dilaksanakan di lingkungan Desa Pundung Putih Ungaran dengan subjek penelitian adalah siswa sekolah dasar. Peneliti melakukan analisis terdapat lima belas nilai karakter dari delapan belas nilai karakter acuan yang terkandung dalam film animasi Moana. Berdasarkan hasil penelitian disimpulkan bahwa setiap siswa dapat menangkap dua sampai enam karakter. Hampir setiap siswa dapat menemukan nilai karakter jujur, kerja keras dan peduli lingkungan dalam film. Kesimpulannya film animasi Moana dapat dijadikan sebagai contoh penanaman nilai-nilai karakter pada siswa sekolah dasar dan dapat dijadikan sebagai media dalam mengembangkan nilai-nilai karakter dengan tetap memerlukan pendampingan dari guru dan orang tua
\end{abstract}

Keywords: Nilai karater, Film Moana, Siswa Sekolah Dasar

\section{Abstract}

Elementary school students have a high intensity of time watching television at home. Even though there are some shows on television that are not intended for elementary school students. This is the basis for researchers to analyze the character values that exist in the animated film Moana. The aims of this study was to determine the catching power of elementary school students in capturing moral messages and character values in the animated film Moana. This type of research is a qualitative research with descriptive methods. The data collection technique used the method of note taking, interview, observation, and documentation. The research was conducted in the Pundung Putih Village Ungaran with the research subjects were elementary school students. The researcher analyzed fifteen character values from the eighteen reference character values contained in the animated Moana film. Based on the results of the study, it was concluded that each student could capture two to six characters. Almost every student can find the value of honest, hard-working, and caring character in the film. In conclusion, Moana's animated film can be used as an example of instilling character values in elementary school students and can be used as a medium in developing character values while still requiring assistance from teachers and parents

Keywords: Character Value, Moana film, Elementary School Students

$\begin{array}{ll}\text { History: } & \text { Publisher: Undiksha Press } \\ \text { Received: 4 Juni } 2020 & \text { Licensed: This work is licensed under } \\ \text { Revised: } 1 \text { Juli } 2020 & \text { a Creative Commons Attribution 3.0 License } \\ \text { Accepted: 20 Juli } 2020 & \end{array}$




\section{Introduction}

Keberhasilan Pendidikan karakter membantu manusia dalam membentuk potensipotensi kemanusiaan yang ada dalam diri manusia. Potensi kemanusiaan merupakan dasar untuk mengembangkan diri seseorang menjadi manusia yang beradab. Untuk menjadi manusia beradab, nilai-nilai luhur perlu ditanamkan melalui pendidikan. "Pendidikan karakter menurut Zubaedi adalah usaha sengaja (sadar) untuk mewujudkan kebajikan, yaitu kualitas kemanusiaan yang baik secara objektif, bukan hanya baik untuk individu perseorangan, tetapi juga baik untuk masyarakat secara keseluruhan. Pendidikan karakter dimaknai sebagai pendidikan yang mengembangkan nilai-nilai karakter pada peserta didik sehingga mereka memiliki nilai karakter sebagai karakter dirinya, menerapkan nilai-nilai tersebut dalam kehidupan dirinya sebagai anggota masyarakat warga negara yang relegius, nasionalis, produktif, dan kreatif'(Putry, 2019b).

Nilai-nilai yang ditanamkan akan membentuk karakter pada diri manusia yang akan menentukan suatu bangsa itu adalah bangsa yang maju atau bangsa yang mundur. Menyadari hal tersebut pemerintah mengupayakan menciptakan generasi bangsa yang berkarakter melalui pendidikan. Berdasarkan Undang-Undang Nomor 20 Tahun 2003 Pasal 3 Pendidikan nasional berfungsi mengembangkan kemampuan dan membentuk watak serta peradaban bangsa yang bermartabat dalam rangka mencerdaskan kehidupan bangsa. Bertujuan untuk berkembangnya potensi peserta didik agar menjadi manusia yang beriman dan bertakwa kepada Tuhan Yang Maha Esa, berakhlak mulia, sehat, berilmu, cakap, kreatif, mandiri, dan menjadi warga negara yang demokratis serta bertanggung jawab. Mengembangkan pendidikan karakter siswa dalam rangka membentuk manusia yang bermartabat agar dapat memenuhi kriteria pada Undang- Undang Nomor 20 Tahun 2003 Pasal 3 dalam ayat tersebut, maka, diperlukan adanya kerja sama antara pembuat kebijakan dengan pelaksana pembelajaran. Siswa merupakan objek sebagai pelaksana pembelajaran yang memiliki peran penting dalam penguatan penanaman pendidikan karakter.

Pendidikan karakter memiliki tujuan utama dalam membentuk manusia yang bermartabat dan mencerdaskan kehidupan bangsa dipengaruhi oleh berbagai faktor. Salah satu faktor yang ikut mempengaruhi keberhasilan pendidikan karakter adalah menunjukkan kemampuan berfikir logis, kritis, kreatif, dan inovatif pada anak dalam proses kegiatan belajar mengajar. Kemampuan tersebut diperlukan untuk mengetahui tercapai atau tidak proses pendidikan karakter bagi siswa sekolah dasar.

Kemampuan berfikir dalam menangkap pembelajaran antara peserta didik satu dengan yang lain berbeda, hal tersebut dipengaruhi oleh daya tangkap atau daya serap siswa dalam menangkap informasi dan pengetahuan yang membutuhkan waktu dan pemahaman yang berbeda antara peserta didik. Menurut Kamus Besar Bahasa Indonesia, daya diartikan sebagai kemampuan untuk melakukan sesuatu atau kemampuan untuk bertindak, sedangkan kata serap diartikan sebagai memahami dengan sungguh. Jadi daya serap dapat diartikan sebagai kemampuan seseorang untuk melakukan sesuatu dengan cara sungguh-sungguh. "Menurut Iswahyudi (2009:16), daya serap siswa adalah kemampuan menyerap suatu konsep atau materi pelajaran yang disampaikan oleh pendidik dengan kesadaran memanfaatkan daya guna dalam menjalankan pemahaman atas pelaksanaan yang sejalan dengan tuntutan perubahan" (Nugroho, 2017). Sedangkan menurut Thorifin dan Ni'amul Huda (2016:52) daya serap adalah kemampuan mengambil, menyimpan, merespons apa yang dipelajari dari orang lain, seperti guru dan yang lainnya (Fauzi, 2017).

Pada era globalisasi yang semakin tidak ada batasnya ini masyarakat tidak dapat menolak adanya perkembangan teknologi informasi khususnya televisi. Saat ini televisi telah menjadi salah satu kebutuhan pokok manusia untuk mendapatkan informasi, hiburan dan menambah wawasan. Kontroversi tentang dampak yang ditimbulkan televisi terhadap anak kelihatannya tidak pernah selesai. Jumlah jam menonton anak merupakan salah satu dampak 
yang ditimbulkan dari intensitas menonton televisi. Berdasarkan data Kompas edisi 16 Juli 2012, diketahui fakta tentang pertelevisian di Indonesia, menyatakan intensitas waktu menonton acara televisi di enam kota (Jakarta, Bandung, Semarang, Surabaya, Medan dan Makasar), berdasarkan umur responden yang diwakili semua kelompok sosial ekonomi, diketahui bahwa anak kurang dari 4 tahun menonton televisi antara 2,5 - 3 jam/hari, usia 4 14 tahun menonton televisi antara 3 - 5 jam/hari, dan pada usia 14-25 tahun menonton televisi antara 1 - 2,5 jam/hari. Sedangkan pada hari Minggu dapat mencapai 5 - $7 \mathrm{jam} / \mathrm{hari}$. (Setiyanto, 2015).

Tayangan-tayangan yang dipertontonkan dalam televisi umumnya sedikit sekali yang dikemas untuk khalayak anak-anak. Kurangnya keberpihakan televisi kepada anak-anak menjadi salah satu penyebab kekhawatiran terhadap dampak yang akan terjadi kepada mereka. Hanya beberapa program acara yang dapat dinikmati anak-anak salah satunya adalah tayangan animasi berjudul "Adit Sopo Jarwo". Rating "Adit Sopo Jarwo" masuk 10 besar tayangan favorit yang mencapai program rating2,9 sharing 14 pada 29 September 2017 (Arya, 2017; Ginanjar \& Saleh, 2020)

Tayangan kesukaan anak-anak adalah tayangan film televisi dalam bentuk animasi. Secara umum animasi adalah suatu proses menggambar dengan memodifikasi gambar dari tiap-tiap frame yang ditampilkan pada sebuah layar (Leonardi Yudistira, Rotinsulu, Hans F. Wowor, 2015). Banyak sekali film animasi yang telah tayang di berbagai stasiun televisi di Indonesia, hal ini karena film animasi adalah film yang cocok diberikan kepada anak-anak. Film animasi sendiri biasanya memiliki jalan cerita yang ringan, memiliki Bahasa komunikatif yang dapat mudah ditangkap dan memiliki pesan moral yang terkandung didalaminya. Salah satu film animasi yang pernah ditayangkan di Indonesia adalah film animasi Moana yang di produksi oleh dreamwork's animation. Film ini menceritakan tentang seorang anak bernama Moana, yang memiliki semangat dan rasa keingintahuan yang tinggi tentang siapa sebenarnya dirinya. Hail tersebut tidak jauh berbeda dengan kehidupan anak sekolah pada zaman sekarang yang memiliki rasa ingin tahu yang tinggi dan sikap meniru dari apa yang dilihat, sehingga diperlukan pendidikan karakter sebagai fondasi anak dalam menghadapi tuntunan zaman yang semakin berkembang.

Pendidikan karakter merupakan pendidikan yang mengembangkan nilai-nilai budaya dan karakter bangsa, sehingga mereka memiliki dan menerapkan nilai-nilai tersebut dalam kehidupan dirinya sebagai anggota masyarakat dan warga negara yang religius, produktif, dan kreatif (Putry, 2019a; Suyitno, 2017). Menyatakan terdapat delapan belas nilai karakter yang harus ditanamkan pada diri anak, yaitu nilai religius, jujur, toleransi, disiplin, kerja keras, kreatif, mandiri, demokratis, rasa ingin tahu, semangat kebangsaan, cinta tanah air, menghargai prestasi, bersahabat/komunikatif, cinta dalam, gemar membaca, peduli lingkungan, peduli sosial, dan tanggung jawab (Maunah, 2016; Tantri, 2017). Abagail setiap anak memiliki karakter di atas maka akan menjadi manusia yang berkualitas, namun kenyataannya masih banyak ditemui berbagai penyimpangan karakter yang dilakukan oleh anak-anak di zaman sekarang. Pada masa sekarang dimana media internet dan media massa sangat berpengaruh besar dalam pendidikan pada anak sekolah dasar salah satunya media televisi dimana anak- anak menghabiskan banyak waktu di depan televisi untuk menonton tayangan-tayangan yang ada. Film merupakan refleksi dari kehidupan sosial masyarakat yang juga mengandung penerapan moral dalam sikap dan tingkah laku para tokoh sesuai dengan pandangannya tentang moral (Lukmantoro et al., 2019) Melalui cerita yang ditampilkan dalam film serta tingkah laku tokoh dalam film para penonton film diharapkan dapat mengambil pesan moral yang disampaikan pada suatu film.

Berdasarkan wawancara dengan siswa sekolah dasar di lingkungan Desa Pundung Putih, anak-anak memiliki intensitas waktu yang sering dalam menonton tayangan televisi ketika berada di rumah, tayangan-tayangan yang sering di tonton adalah tayangan animasi 
seperti Upin dan Ipin, SpongeBob SquarePants dan Power Ranger. Dari tontonan tersebut terdapat beberapa tayangan yang sebenarnya tidak baik diberikan kepada siswa sekolah dasar karena terdapat beberapa adegan kekerasan. Peneliti juga melakukan wawancara dengan beberapa guru Sekolah dasar di lingkungan Desa Pundung Putih mengenai nilai karakter anak siswa sekolah dasar pada masa sekarang di antaranya siswa sekolah dasar khususnya kelas rendah masih banyak bergerak dan aktif, tidak mudah diatur sehingga membuat guru harus memiliki cara agar siswa dapat tenang, coba-coba dalam segala hal yang menarik perhatian siswa baik itu di luar kelas maupun di dalam kelas, Dari hasil wawancara didapatkan bahwa tidak semua film animasi layak untuk ditonton oleh anak-anak ada beberapa film animasi yang sebenarnya tidak diperuntukkan untuk anak-anak karena mengandung unsur kekerasan atau mengandung sedikit unsur pornografi yang tidak baik untuk dikonsumsi oleh siswa sekolah dasar. karena pada dasarnya anak-anak memiliki kecenderungan untuk meniru dan mempraktikkan apa yang biasa dilihat baik ketika berada di rumah maupun di kelas. Berdasarkan hal tersebut maka peneliti tertarik membahas mengenai nilai-nilai karakter yang dapat ditangkap oleh siswa sekolah dasar dalam film animasi Moana karya dreamwork's animation.

Berdasarkan penelitian sebelumnya yang dilakukan oleh Nur Aftah Khoiriyah pada tahun 2016 dengan judul "Analisis Nilai Karakter dalam Film Adit dan Sopo Jarwo Karya Anak Bangsa" dan penelitian yang dilakukan oleh Diah Saraswati pada tahun 2016 dengan judul "Analisis Nilai Karakter dalam Film Animasi Keluarga Somat". Penelitian tersebut menunjukkan bahwa film animasi mempunyai pengaruh yang signifikan terhadap nilai-nilai karakter pada siswa sekolah dasar. Hal ini terbukti dari penelitian sebelumnya yang dilakukan oleh Putri Noor Rohmawati pada tahun 2017 dengan judul "Analisis Nilai Karakter dalam Film Animasi Wreck It Ralph dalam penelitian tersebut menunjukkan bahwa film animasi Wreck It Ralph layak dijadikan sebagai contoh penanaman nilai karakter pada anak karena pada film tersebut memuat seluruh 18 nilai karakter yang menjadi acuan pendidikan karakter yang dapat digunakan sebagai sarana pembelajaran pendidikan karakter bagi anak usia sekolah dasar.

Berdasarkan penyampaian di atas tujuan penelitian ini adalah untuk menganalisis dan mendeskripsikan pesan moral dan nilai karakter pada film animasi Moana terhadap daya tangkap siswa sekolah dasar dalam menangkap pesan moral dan nilai-nilai karakter.

\section{Materials and Methods}

Penelitian ini menggunakan pendekatan penelitian kualitatif, jenis penelitian ini termasuk dalam penelitian deskriptif kualitatif. Creswell dalam Sugiyono, (2017:41), menjelaskan pendekatan yang digunakan adalah deskriptif kualitatif yang dilakukan dengan cara mendeskripsikan atau memaparkan fakta-fakta atau data-data yang diperoleh dari sumber data. Penelitian ini dilaksanakan di Desa Pundung Putih Ungaran Timur.

Subjek dalam penelitian ini adalah Guru SD Sidomulyo 03, Guru MI Gedang anak, Guru SDN Leyangan dan siswa sekolah dasar kelas tinggi dan rendah di lingkungan Desa Pundung Putih. Prosedur pengumpulan data dengan menggunakan teknik simak catat, wawancara, observasi dan dokumentasi. Teknik simak catat dilakukan dengan menganalisis dan menyimak sumber data dalam film animasi Moana kemudian mencatat hasil analisis dengan menggunakan tabel nilai karakter. Pada penelitian ini peneliti menggunakan wawancara tidak struktur untuk memperoleh informasi awal pada saat pengumpulan data. Peneliti mewawancarai empat siswa sekolah dasar yang terdiri dari kelas tinggi dan rendah serta guru sekolah dasar di lingkungan Desa Pundung Putih. Wawancara digunakan untuk mengetahui informasi mengenai nilai karakter pada siswa sekolah dasar. Pada penelitian ini dilakukan dengan menggunakan observasi tidak terstruktur dimana observasi tidak dipersiapkan secara sistematis, dalam pengamatan peneliti tidak menggunakan instrumen 
yang baku dan bebas melakukan pengamatan dan mencatat hal-hal yang menarik penelitian. Dalam penelitian ini peneliti melakukan pengamatan dengan menggunakan film animasi Moana sebagai dokumen karya sastra.

Untuk mengecek keabsahan data dalam penelitian ini digunakan pendekatan ketekunan/keajegan pengamatan bermaksud menemukan ciri-ciri dan unsur-unsur dalam situasi yang sangat relevan dengan persoalan atau isu yang sedang dicari dan kemudian memusatkan diri pada hal-hal tersebut secara rinci. Pada penelitian ini peneliti menggunakan dokumen-dokumen yang berkaitan dengan temuan yang diteliti mengenai nilai nilai karakter dalam film animasi sehingga mampu memperluas wawasan dan digunakan untuk memeriksa data yang ditemukan apakah data tersebut valid atau tidak.

Menguji keabsahan data dalam penelitian kualitatif meliputi uji kredibilitas atau kepercayaan terhadap data hasil penelitian kualitatif antara lain dilakukan dengan triangulasi data. Triangulasi menurut Lexy J. Moeleong adalah teknik pemeriksaan keabsahan data yang memanfaatkan sesuatu yang lain diluar data itu untuk keperluan pengecekan atau sebagai pembanding terhadap data itu. Penelitian ini menggunakan penelitian triangulasi sumber data. Triangulasi sumber data dilakukan dengan cara mengecek data yang telah diperoleh melalui beberapa sumber. Dalam penelitian ini sumber data didapat dari empat orang siswa sekolah dasar dan tiga orang guru sekolah dasar yang berbeda di lingkungan Desa Pundung Putih. Pemeriksaan dengan Teman Sejawat Menurut Moleong (2012:334) diskusi dengan teman sejawat merupakan pemeriksaan dengan mengumpulkan teman-teman sebaya, sehingga dapat bersama-sama me-rivew analisis tentang penelitian yang sedang dilakukan. Diskusi dengan teman sejawat ini dilakukan dengan bersama teman sejawat menonton film animasi Moana kemudian mendiskusikan temuan hasil pengamatan yang didapat dari menonton film. Melalui diskusi dengan teman sejawat, peneliti dapat menemukan hal baru untuk mengurangi kekurangan dalam penelitian ini sehingga didapat temuan hasil penelitian yang valid.

Prosedur pengumpulan data dengan menggunakan teknik simak catat, wawancara, observasi dan dokumentasi. Teknik simak catat dilakukan dengan menganalisis dan menyimak sumber data dalam film animasi Moana kemudian mencatat hasil analisis dengan menggunakan tabel nilai karakter. Pada penelitian ini peneliti menggunakan wawancara tidak struktur untuk memperoleh informasi awal pada saat pengumpulan data. Peneliti mewawancarai empat siswa sekolah dasar dan guru sekolah dasar. Wawancara digunakan untuk mengetahui informasi mengenai nilai karakter pada siswa sekolah dasar. Observasi dilakukan dengan melakukan pengamatan tidak terstruktur dengan menggunakan film animasi Moana, dalam pengamatan peneliti tidak menggunakan instrumen yang baku dan bebas melakukan pengamatan dan mencatat hal-hal yang menarik penelitian. Dalam penelitian ini peneliti melakukan pengamatan dengan menggunakan film animasi Moana sebagai dokumen karya sastra.

Teknik analisis data pada penelitian ini adalah menggunakan teknik analisis kualitatif dengan model Miles and Huberman dimana aktivitas menggunakan pengumpulan data, reduksi data, penyajian data dan langkah terakhir adalah penarikan kesimpulan. Menurut Miles and Huberman dalam Sugiyono, (2016: 338-341) ada tiga macam kegiatan dalam analisis data kualitatif yaitu data reduction (reduksi data), data display (penyajian data), conclusion drawing/verification. Data yang akan dianalisis sebelumnya dikumpulkan, data yang dikumpulkan merupakan data yang berasal dari hasil observasi, wawancara, dan dokumentasi dari siswa dan guru mengenai hasil analisis film animasi Moana dilingkungan Desa Pundung Putih.

\section{Results and Discussion}

Berdasarkan hasil analisis peneliti dalam mengenalisis film animasi Moana, terdapat 15 nilai nilai karakter yang terkandung dalam film animasi Moana antara lain: Jujur, 
toleransi, disiplin, kerja keras, kreatif, mandiri, demokratis, rasa ingin tahu tinggi, semangat kebangsaan, menghargai prestasi, komunikatif dan bersahabat, cinta damai, peduli lingkungan, peduli sosial, tanggung jawab. Kelima belas nilai-nilai karakter tersebut disampaikan melalui adegan-adegan serta tokoh-tokoh yang berperan dalam film animasi Moana.

Subjek dari penelitian ini adalah siswa sekolah dasar dengan jumlah empat siswa dan tiga guru sekolah dasar dilingkunganya Pundung Putih. Dari hasil analisis data siswa, siswa memiliki intensitas waktu yang sering dalam menonton tayangan televisi ketika berada di rumah, tayangan-tayangan yang sering ditonton adalah tayangan animasi seperti Upin dan Ipin, Spongbob Squerpants dan Power Ranger. Berdasarkan wawancara peneliti dengan siswa, ada siswa yang belum pernah menonton film animasi moana, dan juga ada siswa yang sudah nonton film animasi moana di televisi. Berdasarkan catatan lapangan selama penelitian ada beberapa siswa yang fokus dan antusias dalam monton film animasi moana dan ada juga yang bermain dengan teman yang lain.

Berdasarkan wawancara dengan guru sekolah dasar di lingkungan Desa Pundung Putih mengenai tayangan yang ditonton oleh anak-anak, terdapat beberapa tayangan yang sebenarnya tidak baik diberikan kepada siswa sekolah dasar karena terdapat beberapa adegan kekerasan. Selain itu guru juga mengatakan mengenai nilai karakter anak siswa sekolah dasar pada masa sekarang di antaranya siswa sekolah dasar khususnya kelas rendah masih banyak bergerak dan aktif, tidak mudah diatur sehingga membuat guru harus memiliki cara agar siswa dapat tenang, coba-coba dalam segala hal yang menarik perhatian siswa baik itu di luar kelas maupun di dalam kelas. Dari hasil wawancara didapatkan bahwa tidak semua film animasi layak untuk ditonton oleh anak-anak ada beberapa film animasi yang sebenarnya tidak diperuntukkan untuk anak-anak karena mengandung unsur kekerasan atau mengandung sedikit unsur pornografi yang tidak baik untuk dikonsumsi oleh siswa sekolah dasar. karena pada dasarnya anak-anak memiliki kecenderungan untuk meniru dan mempraktikkan apa yang biasa dilihat baik ketika berada di rumah maupun di kelas.

Dari hasil analisis yang telah dilakukan, pesan moral pada film animasi Moana antara lain: (1) Jangan Pantang Menyerah, Jangan pantang menyerah sebelum benar memberikan hasil yang maksimal karena usaha tidak akan membohongi hasil. (2) Meyakini Diri Sendiri, Percayalah meyakini kekuatan diri sendiri adalah hal yang terbaik untuk membuktikan bahwa kita bisa. (3) Berani meminta maaf dan saling memaafkan, Mencari kesalahan orang lain merupakan cara paling mudah, sementara mencari dan mengakui kesalahan diri sendiri dibutuhkan keberanian dan keikhlasan diri. (4) Butuh usaha untuk mencapai tujuan Butuh usaha untuk mencapai tujuan karena tanpa usaha kita tidak akan mendapatkan apapun tujuan kita, (5) Berani bertanggung jawab Kadang kekuatan kita berada dibalik tampilan luar, Moana membuktikan dengan berani bertanggung jawab atas pesan dan perintah yang telah di berikan. "Jawaban atas pertanyaan yang kau tanyakan pada dirimu sendiri kau ditakdirkan jadi siapa tergantung pada tanggung jawab diri sendiri."

Berdasarkan hasil analisis peneliti dalam menganalisis film animasi Moana, terdapat 15 nilai karakter yang terkandung dalam film animasi Moana antara lain: nilai karakter Jujur, nilai karakter toleransi, nilai karakter disiplin, nilai karakter kerja keras, nilai karakter kreatif, mandiri, nilai karakter demokratis, nilai karakter rasa ingin tahu tinggi, nilai karakter semangat kebangsaan, nilai karakter menghargai prestasi, nilai karakter komunikatif dan bersahabat, nilai karakter cinta damai, nilai karakter peduli lingkungan, nilai karakter peduli sosial, nilai karakter tanggung jawab. Kelima belas nilai-nilai karakter tersebut disampaikan melalui adegan-adegan serta tokoh-tokoh yang berperan dalam film animasi Moana. Dari hasil analisis siswa sekolah dasar dapat menangkap 9 nilai karakter yaitu nilai karakter (1) Jujur, (2) Disiplin, (3) Tanggung jawab, (4) Demokrasi, (5) Kerja keras, (6) Mandiri, (7) Bersahabat, (8) Cinta Damai, (9) Peduli lingkungan. Jadi pada siswa kelas tinggi dapat 
menangkap tiga sampai lima nilai karakter sedangkan pada siswa kelas rendah dapat menangkap dua sampai tiga nilai karakter Hampir setiap siswa dapat menemukan nilai karakter jujur, kerja keras dan peduli lingkungan dalam film.

Dalam penelitian, peneliti menemukan temuan lain yaitu pada siswa sekolah dasar pada jenjang yang berbeda yaitu siswa kelas tinggi dan siswa kelas rendah ditemukan melalui pengamatan secara langsung siswa kelas tinggi memiliki konsentrasi yang baik ketika menonton film, tidak bermain dengan yang lain, siswa juga memiliki ketertarikan akan film animasi Moana dan memiliki pengetahuan mengenai nilai-nilai karakter sehingga siswa kelas tinggi dapat menangkap nilai karakter lebih banyak. Pada siswa kelas rendah cenderung masih sering bermain dan tidak berkonsentrasi pada film serta pengetahuan mengenai nilainilai karakter yang masih kurang yang membuat siswa kelas rendah tidak dapat menyebutkan semua nilai-nilai karakter.

\section{Conclusion}

Berdasarkan hasil peneltian dan pembahasan dapat disimpulkan pada film animasi Moana siswa sekolah dasar dapat menangkap 9 nilai karakter yaitu nilai karakter jujur, nilai karakter disiplin, nilai karakter tanggung jawab, nilai karakter, demokarasi, nilai karakter, kerja keras, nilai karakter mandiri, nilai karakter bersahabat, nilai karakter cinta dalam, nilai karakter peduli terhadap lingkungan. Nilai karakter tersebut disampaikan melalui adeganadegan serta tokoh yang berperan dalam film animasi Moana. Berdasarkan hasil analisis serta wawancara dengan siswa dan guru sekolah dasar maka film animasi moana dapat dijadikan sebagai contoh penanaman nilai-nilai karakter pada siswa sekolah dasar dan dapat dijadikan sebagai media dalam mengembangkan nilai-nilai karakter dengan tetap memerlukan pendampingan dari guru dan orang tua.

\section{References}

Agus Wibowo.2017. Pendidikan Karakter: Strategi membangun karakter berperadaban: Pustaka Pelajar.

Fauzi, A. (2017). Daya Serap Siswa Terhadap Pembelajaran Taksonomi Pendidikan Agama Islam. Jurnal Pusaka.

Ginanjar, D., \& Saleh, A. (2020). Pengaruh Intensitas Menonton Film Animasi Adit Sopo Jarwo Terhadap Interaksi Sosial Anak Sekolah Dasar. Jurnal Komunikasi Pembangunan. https://doi.org/10.46937/18202028110

Kustadi, Cecep dan Bambang Sutjipto.2013. Media Pembelajaran Manual dan Digital. Bogor: Ghalia Indonesia

Leonardi Yudistira, Rotinsulu, Hans F. Wowor, S. D. S. K. (2015). Animasi 3d Sosialisasi Penanganan Rabies Pada Masyarakat Dengan Waterfall Yang Disederhanakan. Jurnal Teknik Elektro Dan Komputer, Volume 4, N. https://doi.org/10.35793/jtek.4.4.2015.8970Moleong, Lexy J.2013.

Metode Peneltian Kualitatif. Bandung: PT Pemaja Rosda Karya

Munawaroh,Ririn Layfatul dkk.2019. Nilai Karakter dalam Film Harton Hears A Who Sudut Pandang. Indonesian Values and Character Education Journal. Vol. 2, No 1

Muslich, Mansur.2011.Pendidikan Karakter: Menjawab Tantangan Krisis Multidimonsional. Jakarta: PT Bumi Aksara

Nugroho, F. P. (2017). Faktor-Faktor yang mempengaruhi Daya Serap Siswa pada Mata Pelajaran Ekonomi. Pendidikan Dan Ekonomi. 
Putry, R. (2019). Nilai Pendidikan Karakter Anak Di Sekolah Perspektif Kemendiknas. Gender Equality: International Journal of Child and Gender Studies. https://doi.org/10.22373/equality.v4i1.4480.

Setiyanto, donik agus. (2015). Pengaruh Intensitas Menonton Televisi dan Pendampingan Orangtua dalam Menonton Televisi Terhadap Kedisiplinan Belajar Disusun untuk memenuhi persyaratan menyelesaikan Pendidikan Strata 1 Penyusun Nama NIM: Donik Agus Setiyanto. 1-13.

Sulistyowati, Endah. 2012. Implementasi Kurikulum Pendidikan Karakter. Yogyakarta. Citra Aji Pramana.

Wibowo A. 2013. Manajemen Pendidikan Karakter di Sekolah: Konsep dan Politik Implementasi. Yogyakarta: Pustaka Pelajar. 